Снежана С. Стојшин ${ }^{1}$

УДК $911.373: 314.04(497.11)$

Универзитет у Новом Саду

https://doi.org/10.18485/ssd_sddc.2021.ch10

Филозофски факултет

Одсек за социологију

\title{
ДРУШТВЕНИ РАЗВОЈ И ДЕМОГРАФСКЕ ПРОМЕНЕ У СРПСКИМ СЕЛИМА - АНАЛИЗА ПОКАЗАТЕЉА
}

Апстракт: У раду се говори о показатељима који су се у досадашњим, најчешће социолошким и демографским истраживањима и анализама, углавном користили у праћењу друштвених промена које карактеришу села у Србији последњих неколико деценија. Показатељи који су се користили у анализи друштвеног развоја неког села, групе села одређене области, или српског села уопште, подељени су на друштвене, демографске и економске. Након анализе карактеристика корисности ових група показатеља, и најчешће коришћених показатеља појединачно, указано је на њихову међусобну повезаност и прожетост, која резултира широким детерминистичким сплетом показатеља и не могу се посматрати засебно. У анализи ових показатеља посебна пажња посвећена је демографским показатељима, а анализирани су демографски показатељи који се односе на етничку групу Румуна који у највећој мери у Војводини живе у сеоским срединама. Међу показатељима се у досадашњим анализама и истраживањима најчешће користило кретање броја становника, природно кретање становништва, односно анализа стопа наталитета и морталитета, удео пољопривредног становништва.

Кључне речи: друштвени развој, демографске промене, село, показатељи, Румуни.

\section{Увод}

Показатеље који су се у досадашњим истраживањима користили у анализи друштвеног развоја неког села, групе села одређене области, или

\footnotetext{
1 snezanas@ff.uns.ac.rs

2 Рад је настао у оквиру пројекта "Српско село између традиције и сталних промена" који се реализује у Матици српској, а који је подржан од стране Министарства просвете, науке и технолошког развоја и Покрајинског секретаријата за високо образовање и науку.
} 
српског села уопште, можемо поделити на друштвене, демографске и економске. Имајући у виду да руралну друштвену структуру чине: а) сеоска насеља и становништво (демографска подструктура), б) сељачка економија и аграрни односи, в) локална друштвена организација и г) обрасци сеоске народне културе који прожимају остале структуре и усмеравају сељачки начин живота (Митровић, 2015:19), јасно је зашто у изучавању показатеља развоја села треба почети анализом демографских карактеристика.

Демографске промене које су последњих деценија захватиле српска села указују на неколико специфичности. Прва, и рекло би се најупечатљивија карактеристика већине села у Србији јесте континуирано смањење броја становника. Смањење броја становника који живе у сеоским срединама константно се бележи након Другог светског рата, а удео сеоског становништва смањио се са 77,5\% колико је износио 1953. године, на 40,6\% колико износи према последњем попису 2011. године (Р3С, 2014). Пописом 1991. године први пут је у Србији забележено више градског него сеоског становништва. Најмање сеоског становништва данас има у региону Београда, 18,9\% од укупног броја становника региона, а највише сеоског становништва има у региону Шумадије и Западне Србије, 52,2\% укупног становништва тог региона. У Војводини 40,6\% становништва живи на селу (Р3С, 2014). Међутим, треба рећи да депопулација превазилази деаграризацију (Митровић, 2015), такође једну од карактеристика српских села, јер људи напуштају како села, тако и пољопривреду. Пошто је у овим селима већином пољопривредно становништво, „депопулација села манифестује и као сенилизација (старење) и девастација (запуштање) пољопривреде и свих сеоских подручја удаљених од главних комуникација“ (Митровић, 2015:40). Ова села углавном су напуштена од већих градова и општинских центара, у њима нема индустријских погона, нити добре комуналне и социјалне инфраструктуре, те се тешко може се говорити о развојној перспективи села.

Даље, као друга карактеристика, односно показатељ (не)развоја сеоских подручја издвајају се негативне промене у старосним структурама становништва. Под овим негативним карактеристикама подразумева се повећање удела старог становништва и смањење удела младог становништва у укупном броју становника. У Србији је пописом 2002. године први пут забележен већи удео старих (64+), него младих (млађи од 
15 година) лица (Стојшин, 2018: 78), а након овог периода, процес старења се још више интензивирао, па се становништво Србије налази у процесу дубоке демографске старости (просечна старост становништва је 42,2 године, а сваки шести становник старији је од 64 године). Између последња два пописа 2002. и 2011. године, значајно се смањио удео младих у свим местима Србије, са $15,8 \%$ на $14,3 \%$ од укупног становништва, док је удео старих повећан са 16,7\% на 17,4\% (Р3С, 2012). Највећи удео старог становништва, 19,4\%, има регион Јужне и Источне Србије.

Становништво сеоских подручја је још старије. Подаци показују да је удео старог становништва у РС у сеоским срединама 20,1\% (Р3С, 2012). Најстарије је сеоско становништво Источне и Јужне Србије, где удео старог у укупном сеоском становништву износи $24,2 \%$, што значи да је сваки четврти становник села у овом региону старији од 65 година. Нешто мањи удео старог становништва у укупном сеоском становништву има регион Шумадије и Западне Србије 20,6\%, док је у Војводини 17,3\% сеоског становништва старије од 65 година (РЗС, 2012).

Трећа карактеристика српских села, која је уједно и индикатор развоја, односи се на висину удела пољопривредног становништва, а подаци показују његово константно смањење. Удео пољопривредног становништва у Републици Србији 2011. године износио је $17,1 \%$ од укупног становништва. Највећи удео пољопривредног становништва карактеристичан је за регион Шумадије и Западне Србије 25,4\%, затим за Јужну и Источну Србију 22,1\%, док се у Војводини 13,7\% становништва бави пољопривредом. Најмање пољопривредника забележено је у Београдској области, свега 3,6\% (Попис 2011, Р3С, 2013). У Србији је последњим пописом регистровано 631.552 пољопривредна газдинства, а просечна старост носилаца породичног пољопривредног газдинства је 59 година. Просечно породично газдинство у Србији има 4,5 хектара пољопривредног земљишта, има један двоосовински трактор, једно говедо, четири свиње, три овце и 26 комада живине (Р3С, 2013).

Највећи удео пољопривредних домаћинстава у својој етничкој групи у Војводини имају Румуни (попис 2011). У наредним редовима, општи показатељи развоја села о којима је било речи у претходним редовима, биће допуњени и објашњени на примеру румунске етничке групе која у 
Војводини има највећи удео пољопривредних домаћинстава и углавном $(3 / 4$ од укупног броја Румуна) живи на селу.

\section{Карактеристике румунске сеоске заједнице}

Стојшин наводи (2018: 88-89) да су на данашњу етничку слику Војводине утицале три групе друштвених фактора: пре свега, рат на простору бивше Југославије, који је „донео“ имиграцију највећег броја Срба од колонизације након Другог светског рата, али и емиграцију одређеног броја припадника различитих етничких група; даље, на кретање броја припадника етничких група делују фактори природног кретања становништва, односно негативан природни прираштај који је каркатеристичан за све етничке групе, а који је у директној вези са друштвеним факторима - друштвеном кризом, сиромаштвом, незапосленошћу; трећа група фактора су лично опредељење, односно промена у националном изјашњавању (бивши Југословени, нпр.) (Стојшин 2018: 88-90).

На данашњу територијалну распрострањеност Румуна у Србији утицале су стихијске миграције Румуна пред турским освајачима, затим економски разлози као и планско насељавање Румуна у Војводини (Бјељац, 2006: 376). Румуни су у део који данас обухвата Банат у Војводини колонизовани у 18. и 19. веку углавном из источних делова Баната, Ердеља и Олтеније (Маран, 2014: 69), а највећа насеља у којима су се настанили нпр. Алибунар, Селеуш, Николинци, Локве, Банатско Ново Село, Владимировац и др. била су основана на територији Војне границе (исто, 70). У првим белешкама о Румунима на овом простору, види се да су припадници ове етничке групе били претежно рурално становништво, односно да су се бавили земљорадњом и сточарством, а трговина и занатство биле су присутне у веома малој мери (Маран, 2014: 70). Иако порекло Румуна у Србији датира још од почетка 18. века (Радушки, 2020: 146), Румуни се према пописима као посебна етничка група у Србији прате од 1948. године (до тада су били заједно са Цинцарима), првог послератног пописа до данас, тако да се подаци могу поредити.

Према попису из 1921. године број Румуна који је живео у тадашњој Краљевини СХС износио је 213.068, док је у Србији живело 159.549 Румуна (Бјељац, 2006, Радушки, 2020). Међутим, ове податке треба узети са 
резервом пошто су према тадашњем попису у исту групу сврстани и Румуни и Цинцари.

Иако Румуни у укупном броју становника у Србији немају велики удео (0,4\% укупног становништва, 29.332 становника према попису 2011.), у Војводини су увек представљали не само бројчано значајну етничку групу, што ће показати и наредни редови. Румуни $(1,3 \%)$ са Мађарима којих у Војводини има $13 \%$ у укупном становништву, Ромима (2,2\%), Словацима $(2,6 \%)$, Хрватима $(2,4 \%)$ и Црногорцима $(1,1 \%)$ чине групу етничких заједница бројнијих од 20.000 (РЗС, 2012а). Ове етничке групе су најстарије и налазе се у дубокој демографској старости: просечна старост Мађара према последњем попису је 45,0; Црногораца 46,5; Хрвата 51,0; Румуна 44,6. Из ове групе издвајају се једино Роми као најмалађа етничка група у Србији са просечном старошћу од 28,3 године (попис 2011; Ђурић 2014).

\section{Методологија истраживања}

За анализу демографских карактеристика Румуна као етничке групе узети су подаци пописа који се врши у Србији, затим подаци виталне статистике и малобројна доступна литература. Пописи становништва се у Србији врше сваких десет година, а последњи попис становништва урађен је 2011. године. Посебан проблем у пописним подацима представља то што подаци пописа често нису укрштени са подацима о националној припадности. Подаци у доступној научној литератури углавном су историјски.

\section{Кретање броја Румуна у Војводини}

Према попису 2011. године у Републици Србији живи 29.332 Румуна, од тога 25.410 у Војводини (86,6\% од укупног броја Румуна у Србији), 2.073 у Југоисточној Србији (7,1\% од укупног броја Румуна), 1.282 у региону Београда (4,4\%), док најмање Румуна живи у Западној Србији 567 (1,9\%) (Р3С, 2012a). У раду ће бити анализирана демографска обележја Румуна у Војводини, пошто 86,6\% њих од укупног броја у Србији живи на овој територији.

Скоро три четвртине од укупног броја Румуна у Војводини живи на селу (табела 1). Пре тридесет година, према попису 1991. године чак 81,6\% Румуна живело је у сеоским насељима, а 2011. године тај удео се смањио на 
73,7\%. Овакав податак не изненађује, јер треба имати у виду да се већина Румуна бави пољопривредом, о чему ће бити речи у наредним редовима.

Табела 1. Тип насеља

\begin{tabular}{l|l|l}
\hline & 1991 & 2011 \\
\hline Војводина укупно & $38.809(100,00)$ & $25.410(100,0)$ \\
градска насеља & $7.151(18,4)$ & $6.670(26,2)$ \\
сеоска насеља & $31.658(81,6)$ & $18.740(73,7)$
\end{tabular}

Извор: прорачун аутора на основу података РЗС

Румуни, као и остале бројније етничке групе (групе чији број прелази 25.000 становника) бележе и апсолутан и релативан пад броја, а прво смањење броја Румуна у односу на претходни попис бележи се још 1953. године (табела 2). У том петогодишњем периоду (1948-1953) забележено је 2.027 Румуна мање. Иако је крај 50-их и почетак 60-их година прошлог века у Југославији обележио бејби-бум, односно рађање већег броја деце него за време Другог светског рата, број Румуна је између пописа 1953. и 1961. године порастао за свега 23 нова припадника ове етничке групе, а затим је наставио константан пад. Највећи пад у апсолутном броју становника, припадника румунске етничке групе, забележен је између пописа 1981. и 1991. (- 8.457 Румуна мање).

Табела 2. Кретање броја Румуна од 1948. до 2011. у РС и Војводини

\begin{tabular}{l|l|l|l|l|l|l|l|l|}
\hline & 1948 & 1953 & 1961 & 1971 & 1981 & 1991 & 2002 & 2011 \\
\hline Србија & 63.130 & 59.705 & 59.505 & 57.419 & 53.693 & 42.316 & 34.576 & 29.332 \\
& $(0,97)$ & $(0,86)$ & $(0,78)$ & $(0,68)$ & $(0,58)$ & $(0,54)$ & $(0,46)$ & $(0,41)$ \\
\multirow{3}{*}{ Војводина } & 59263 & 57.236 & 57.259 & 52.987 & 47.289 & 38.832 & 30.419 & 25.410 \\
& $(3,6)$ & $(3,3)$ & $(3,1)$ & $(2,7)$ & $(2,3)$ & $(1,9)$ & $(1,5)$ & $(1,3)$
\end{tabular}

Извор: Пописи становништва за дате године; Етноконфесионални мозаик, стр. 99

Напомена: у загради је удео у укупном броју становника Србије и Војводине

Наведено је да у Војводини живи 86,6\% од укупног броја Румуна у Србији. У укупном броју становништва Војводине, Румуни према последњем попису чине 1,3\% становништва и тај удео у укупном броју становника Војводине је најмањи од Другог светског рата (табела 2). Највише припадника ове етничке групе живи у Јужном Банату (70,8\% од укупног 
броја Румуна) и у укуном броју становника ове регије заузимају 6,1\%. Са удаљавањем територије од Румуније, број Румуна опада, те их најмање има у Севернобачком и Сремском округу (табела 3).

Табела 3. Територијална дистрибуција Румуна у Војводини

\begin{tabular}{l|l|l|l}
\hline Регион & Број Румуна & $\begin{array}{l}\text { Удео Румуна у } \\
\text { укупном броју } \\
\text { Румуна у } \\
\text { Војводини }\end{array}$ & $\begin{array}{l}\text { Удео у укупном } \\
\text { становништву } \\
\text { Војводине }\end{array}$ \\
\hline Војводина & 25.410 & 100,0 & 1,32 \\
Западнобачки & 1.340 & 5,3 & 0,71 \\
Јужнобанатски & 18.000 & 70,8 & 6,13 \\
Јужнобачки & 1.270 & 5,0 & 0,21 \\
Севернобанатски & 421 & 1,7 & 0,28 \\
Севернобачки & 76 & 0,3 & 0,04 \\
Средњебанатски & 4.214 & 16,6 & 2,25 \\
Сремски & 89 & 0,4 & 0,03
\end{tabular}

Извор: прорачун аутора на основу података РЗС

Табела 4. Кретање броја Румуна у неким војвођанским општинама

\begin{tabular}{l|l|l|l}
\hline општина & 1991 & 2011 & $\begin{array}{l}\text { Просечан год } \\
\text { пораст }\end{array}$ \\
\hline $\begin{array}{l}\text { Војводина } \\
\text { укупно }\end{array}$ & 38.809 & 25.410 & $-13.399(669.9)$ \\
Вршац & 8.058 & 5.420 & $-2.638(131,9)$ \\
Алибунар & 8.467 & 4.870 & $-3.597(179,8)$ \\
Панчево & 5.003 & 3.173 & $-1.830(91,5)$ \\
Пландиште & 1.404 & 784 & $-620(31)$ \\
Ковачица & 2.674 & 1.543 & $-1.131(56,5)$ \\
Ковин & 1.722 & 1.170 & $-552(27,6)$ \\
Зрењанин & 3.185 & 2.161 & $-1.024(51,2)$ \\
Житиште & 2.552 & 1.412 & $-1.140(57)$ \\
Бела Црква & 1.605 & 842 & $-763(38,2)$
\end{tabular}

Извор: прорачун аутора на основу података РЗС

У свим општинама Јужног и Средњег Баната, где се бележе највећи удели Румуна (и у укупном броју Румуна, али и укупном броју тих регија), у 
последње три деценије забележен је пад броја припадника ове етничке групе (табела 4). Тако је у Вршцу у овом периоду удео Румуна мањи за 32,8\%, у Алибунару се смањио за 42,5\%, у Пландишту за 44,2\%, у Белој Цркви за чак $47,5 \%$.

\section{Природно кретање становништва румунске етничке групе}

у општинама Јужног Баната, где су Румуни најконцентрисанији негативне стопе природног прираштаја бележе се почетком 70-их година година прошлог века, нпр. у Пландишту је први пут забележен 1970. године -1,0\%, а у Алибунару 1971. године -0,5 промила (РЗС, 2012б). Исте године, први пут је код Румуна забележен негативан природни прираштај -3,8\%. Природни прираштај Румуна у последњем међупописном периоду 20022011 износио је -2.182 (Ђурић, 2014: 103). Негативан природни прираштај бележи се и у периоду након последњег пописа до данас (до последњих доступних података) (табела 5.).

Табела 5. Природни прираштај Румуна у Војводини

\begin{tabular}{l|l|l|l|l|l|l|l|l|l|l|l}
\hline Србија & 2008 & 2009 & 2010 & 2011 & 2012 & 2013 & 2014 & 2015 & 2016 & 2017 & 2018 \\
\hline нат. & 284 & 248 & 238 & 187 & 224 & 217 & 225 & 165 & 170 & 217 & 207 \\
морт. & 512 & 525 & 538 & 496 & 443 & 471 & 452 & 397 & 386 & 367 & 362 \\
пп & -228 & -277 & -300 & -309 & -219 & -254 & -227 & -232 & -216 & -150 & -155 \\
\hline
\end{tabular}

\begin{tabular}{l|l|l|l|l|l|l|l|l|l|l|l}
\hline Војвод. & 2008 & 2009 & 2010 & 2011 & 2012 & 2013 & 2014 & 2015 & 2016 & 2017 & 2018 \\
\hline нат. & 214 & 190 & 189 & 156 & 191 & 183 & 202 & 124 & 135 & 185 & 174 \\
морт. & 501 & 497 & 514 & 485 & 435 & 460 & 437 & 382 & 367 & 356 & 344 \\
пп & -287 & -307 & -325 & -329 & -244 & -277 & -235 & -258 & -232 & -171 & -170 \\
\multicolumn{3}{l}{ Извор: прорачун аутора на основу података Р3С }
\end{tabular}

Извор: прорачун аутора на основу података РЗС

Просечна старост Румуна у Србији између два пописа 2002 и 2011. године повећала се са 42,3 на 44,6 године. Према последњим подацима просечна старост становништва у Србији 2018. године била је 43,2 . Просечна старост Румуна у Војводини 2011. године износила је 44,5, и то ову етничку групу сврстава у најстарије становнике Војводине. Наиме, међу етничким групама чија величина прелази 1,5\% укупног становништва Војводине, сличну просечну старост имају и Русини $(44,9)$, Хрвати $(48,6)$, Мађари $(44,8)$. 
Последњи поспис 2011. године показао је да је просечна старост Румуна 42,8, а Румунки 46,1 година (Р3С, 2012а). Просечна старост становништва Војводине 2011. године износила је 41,7 година, а према проценама и последњим доступним подацима 2018. године је 42,8 година што ће сигурно, уз старосну структуру одразити и на све етничке групе.

Индекс старења 2018. године за становништво Војводине износио је 137,4 (РЗС, 2019). Индекс старења 2018. је још већи у Јужном Банату у општинама где су сконцентрисани Румуни, за Алибунар 163,7, Белу Цркву 152,2 , Пландиште 194,3, Вршац 140, а за Панчево 137,9. Већ је речено да Румуни спадају у најстарије етничке групе у Војводини. Удео младог румунског становништва се смањује, па је у периоду између два пописа 2002. и 2011. године у Војводини смањен са $15,3 \%$ на свега $12,7 \%$ (табела 6), док се у истом периоду удео старог становништва повећао са 20,4\% на 20,9\% у укупном броју Румуна на овој територији. 21,3\% румунских домаћинстава је старачко (Ђурић и сар. 2014:142).

Табела 6. Румуни у великим старосним групама 2002-2011

\begin{tabular}{l|l|l|l|l}
\hline \multirow{2}{*}{} & \multicolumn{2}{|l|}{ Република Србија } & \multicolumn{2}{l}{ Војводина } \\
\cline { 2 - 5 } & 2002. & 2011. & 2002. & 2011. \\
\hline укупно & $34.576(100,0)$ & $29.332(100,0)$ & $30.419(100,0)$ & $25.410(100,0)$ \\
$0-14$ & $4.989(14,4)$ & $3.557(12,2)$ & $4.649(15,3)$ & $3.224(12,7)$ \\
$15-64$ & $22.752(65,8)$ & $19.781(67,4)$ & $19.557(64,3)$ & $16.870(66,4)$ \\
$65+$ & $6.835(19,8)$ & $5.994(20,4)$ & $6.213(20,4)$ & $5.308(20,9)$
\end{tabular}

Извор: прорачун аутора на основу података РЗС

\section{Карактеристике брачног и породичног живота Румуна}

Познато је да је за најстарије етничке групе карактеристичан мањи број особа у браку, а већи удео удоваца и удовица у односу на млађе етничке групе. Тако је, на пример, код Румуна према попису 2011. године било 13,8\% обудовелих лица (табела 7), док је код Рома као најмлађе етничке групе свега 7,5\%. У периоду од 1991. до 2011. године значајно је смањен број лица у брачној заједници, са 70,1\% укупног броја Румуна старијег од 15 година, на $57,7 \%$. У истом периоду за скоро $10 \%$ порастао је број неожењених и 
неудатих (табела 7). Међутим, овде се поставља питање да ли је на ове промене утицала промена у методологији пописа или је у питању промена у обрасцима породичног живота.

Наиме, пописом 2011. године, уведена је категорија ванбрачне заједнице која у дотадашњим пописима није постојала. У ванбрачној заједници живи 1.667 Румуна (800 мушкараца и 867 жена) што чини 6,5\% укупног становништва ове етничке групе. То је 10,1\% од оних који живе у брачној и ванбрачној заједници, што после Рома (36,3\%) представља највећи удео (Станковић, Р3С, 2015:217). Не сме се изгубити из вида да повећање старости становништва утиче на раст броја удоваца и удовица, а да се самим тим и смањује удео ожењених и удатих.

Табела 7. Структура према брачном стању

\begin{tabular}{l|l|l}
\hline & 2011 & 1991 \\
\hline неожењени/неудате & 24,1 & 14,3 \\
ожењени/удате & 57,7 & 70,1 \\
удовци/удовице & 13,8 & 12,5 \\
разведени/разведене & 4,4 & 3,3 \\
Извор: прорачун аутора на основу података РЗС
\end{tabular}

У табели 8 приказан је број склопљених бракова међу Румунима и Румункама и припадницима осталих етничких група у периоду од 2003. године до последњих доступних резултата. Током посматраног периода најчешће је склапање брака између Румунки и припадника српске етничке групе. Овај број је у посматраном периоду у паду, али и даље чини најчешћу етничку комбинацију партнера. Што се тиче Румуна, они најчешће склапају брак са Румункама, а затим са Српкињама.

Анализа структуре румунских породица показује да скоро трећина породица, 31,5\%, чини брачни пар са децом, док 21,1\% Румуна живи у пару без деце. У једнородитељским породицама живи 10,1\% Румуна, од тога је 7,5\% мајка са децом, а 2,6\% очева живи са децом. Међу Румунима је 11,1\% двопородичних домаћинстава, а вишепородичних 1,0\%. 23,3\% Румуна живи 
у самачким непородичним домаћинствима, док 2,0\% живи у вишечланим непородичним домаћинствима (Ђурић и сар. 2014:143)

Прво дете Румунке рађају млађе него остале жене у Србији. Наиме, просечна старост Румунки при рођењу првог детета је 22 године, док је просек у РС 29 година (РЗС, 2020). Према последњем попису највише Румунки има двоје $(43,7 \%)$ и једно $(23,3 \%)$ дете, а у последње две деценије повећао се број Румунки које немају децу са 16,6\% Румунки старијих од 15 година на 20,1\% (табела 9).

Табела 8. Закључени бракови према националности супружника

\begin{tabular}{|c|c|c|c|c|c|c|}
\hline националност & 2003 & 2006 & 2009 & 2012 & 2015 & 2018 \\
\hline укупно & $\begin{array}{l}428 \\
(100,0)\end{array}$ & $\begin{array}{l}321 \\
(100,0)\end{array}$ & $\begin{array}{l}223 \\
(100,0)\end{array}$ & $\begin{array}{l}207 \\
(100,0)\end{array}$ & $\begin{array}{l}231 \\
(100,0)\end{array}$ & $\begin{array}{l}272 \\
(100,0)\end{array}$ \\
\hline Румуни/Румунке & $\begin{array}{l}99 \\
(23,1)\end{array}$ & $\begin{array}{l}92 \\
(28,7)\end{array}$ & $71(31,8)$ & $59(28,5)$ & $58(25,1)$ & $63(23,2)$ \\
\hline Румуни/Српкиње & $\begin{array}{l}43 \\
(10,0)\end{array}$ & $\begin{array}{l}53 \\
(16,5)\end{array}$ & $37(16,6)$ & $53(25,6)$ & $47(20,3)$ & $78(28,7)$ \\
\hline Румунке/Срби & $\begin{array}{l}218 \\
(50,9)\end{array}$ & $\begin{array}{l}134 \\
(41,7)\end{array}$ & $88(39,5)$ & $77(37,2)$ & $87(37,7)$ & $97(35,7)$ \\
\hline Румунке/остали & $\begin{array}{l}39 \\
(9,1)\end{array}$ & $\begin{array}{l}28 \\
(8,7)\end{array}$ & $11(4,9)$ & $5(2,4)$ & $29(12,6)$ & $21(7,8)$ \\
\hline Румуни/остале & $\begin{array}{l}29 \\
(6,8)\end{array}$ & $\begin{array}{l}14 \\
(4,4)\end{array}$ & $16(7,2)$ & $13(6,3)$ & $10(4,3)$ & $13(4,8)$ \\
\hline
\end{tabular}

Извор: прорачун аутора на основу података РЗС

Табела 9. Румунке старије од 15 година по броју живорођене деце (у Војводини)

\begin{tabular}{l|l|l|l|l|l|l|}
\hline & Укупно & нема деце & једно & двоје & троје & четири + \\
\hline \multirow{2}{*}{2011} & 11.491 & 2.308 & 2.678 & 5.025 & \multirow{2}{*}{$(.040(9,1)$} & $440(3,8)$ \\
& $(100,0)$ & $(20,1)$ & $(23,3)$ & $(43,7)$ & & \\
& 1691 & 2.818 & 4.165 & 7.090 & $1.586(9,3)$ & $1.314(7,8)$ \\
& 16.973 & $(16,6)$ & $(24,5)$ & $(41,8)$ & &
\end{tabular}

Извор: прорачун аутора на основу података РЗС

Речено је да се у оквиру румунске етничке групе највећи удео становништва бави пољопривредом. Наиме, чак 8,9\% румунских 
домаћинстава бави се пољопривредом, односно привређује само од пољопривредне производње, што чини највећи удео у оквиру неке етниче групе. Након Румуна, највише Влаха 7,3\%, Словака 5,8\% и Мађара 5,6\% (од укупног броја домаћинстава тих етничких група) бави се пољопривредом (Ђурић и сар. 2014:146). У Србији, искључиво од пољопривредне производње живи 2,7\% домаћинстава (исто, 145).

Овако висок удео становништва које привређује искључиво од пољопривреде прати и неповољна образовна структура Румуна. Наиме, највише припадника румунске етничке групе има завршену основну школу $(32,1 \%)$, а затим средњу (29,8\%). Веома је висок и удео становника са непотпуном основном школом 22,4\%, док је у Србији просек $11,0 \%$ становника без завршеног основног образовања. Вишу школу завршило је 4,2\% а високу 7,5\% Румуна (Ђурић и сар., 2014). 3,2\% Румуна је неписмено.

Румунски језик је један од шест званичних језика у АП Војводини, а треба га узети у разматрање јер је језик заправо најуочљивији индикатор етничке припадности. У пописима је присутан од 1948. године. Румунски као матерњи језик навело је 29.075 становника Србије на попису 2011. године, што је за око 250 мање него број Румуна у Србији. “На румунском језику настава је заступљена у девет локалних самоуправа, и то у Алибунару, Белој Цркви, Вршцу, Житишту, Зрењанину, Ковачици, Панчеву, Пландишту и Сечњу, у 15 школа и то у 11 матичних школа за 64 ученика и у седам издвојених одељења са 17 ђака. У просеку у одељењу има пет ђака, што је по један мање него лане." (Dnevnik, 2019).

Попис становништва, домаћинстава и станова 1991. године, први пут после Другог светског рата, обухватао је и категорију вероисповест (религијска припадност). Код румунске популације 1991. године 38.809 становника $(91,61 \%$ од укупног броја) се изјаснило о вероисповести. Односно, 81,6\% изјаснило се као православци, 6,6\% као католици, 2,8\% као протестанти и 0,01\% као припадници јудејске вероисповести. (Бјељац, 2006: 379). 
Као основни показатељи развоја села, наведени су и анализирани најчешће коришћени демографски показатељи: кретање броја становника, удео старог становништва, удео пољопривредног становништва. Ови показатељи, уз још неке карактеристике брачног и породичног живота анализирани су кроз специфичне карактеристике румунске етничке групе у Војводини, групе чијих 70\% становника живи у војвођанским селима и бави се пољопривредом. Ишчекујући резултате наредног пописа становништва, можемо претпоставити још већу девастацију сеоских подручја и још „лошије“ демографске карактеристике сеоског становништва у Србији.

\section{Литература}

Bjeljac, Ž. (2006). Demografsko kretanje rumunske populacije u Vojvodini, Zbornik Matice srpke za društvene nauke, broj 121, str. 375-382.

Definitivni rezultati popisa stanovništva od 31. januara 1921. godine, Beograd: SZS

Maran, M.; Đurić-Milovanović, A. (2014). Kulturna udruženja Rumuna u Vojvodini, Etnološko-antropološke sveske, 24/13, str. 69-84.

Митровић, М (2015). Села у Србији: промене структуре и проблеми одрживог развоја. Боград; Републички завод за статистику.

Ђурић, В.; Танасковић, Д,; Вукмировић, Д. (2014). Етноконфесонални и језички мозаик Србије, Београд: Републички завод за статистику.

Raduški, N. (2020). Položaj Srba u Rumuniji i rumunske nacionalne manjine u Srbiji, Kultura polisa, Br. 41, godina XVII, str. 143-156.

РЗС 2012. Старост и пол, подаци по насељима, Попис становништва 2011. Београд: Републички завод за статистику.

РЗС 2012а. Национална припадност, подаци по општинама и градовима, Попис становништва 2011. Београд: Републички завод за статистику 
Р3С, 2012б. Природно кретање становништва у Републици Србији 1961-2010, Београд: Републички завод за статистику.

РЗС 2013. Попис пољопривреде 2012. године у Републици Србији - први резултати, саопштење, Београд: Републички завод за статистику

РЗС 2014. Упоредни преглед броја становника 1948 до 2011, подаци по насељима, Попис становништва 2011. Београд: Републички завод за статистику.

РЗС 2017. Демографска статистика, Београд: Републички завод за статистику

РЗС 2019. Општине и региони у Србији, Београд: Републички завод за статистику.

Р3С 2020. Жене и мушкарци у Републици Србији, Београд: Републички завод за статистику

Stanković, B. (2015). Bračnost stanovništva, Populacija Srbije početkom 21. veka, Beograd: RZS Popis stanovništva, domaćinstava i stanova 2011.

SZS 1994. Nacionalni sastav stanovništva, Popis stanovništva, domaćinstava i stanova u 1961. 1971, Beograd: Savezni zavod za statistiku.

(1954) Stalno stanovništvo po narodnosti 1948. godine, Beograd: SZS

Стојшин, С. (2018). Становништво - социолошка перспектива, Нови Сад: Филозофски факултет.

U vojvođanskim školama ostalo prazno još 576 prvačkih stolica, Dnevnik objavljeno 14.02.2019 https://www.dnevnik.rs/drustvo/u-vovodanskimskolama-ostalo-prazno-jos-576-prvackih-stolica-14-02-2019. 


\section{Snežana Stojšin}

\section{Summary}

\section{Social development and demographic changes in Serbian villages - indicator analysis}

The paper discusses indicators that have so far, most often in sociological and demographic research and analyses, been used to track social changes which have characterized the villages in Serbia in the last few decades. The indicators that have been used in the analysis of the social development of a village, a group of villages in a certain region, or the Serbian village in general are divided into social, demographic and economic. After the analysis of the usefulness of these groups of indicators and most often used indicators individually, the paper points out their mutual connections and influence, which result in a wide deterministic set of indicators which cannot be observed individually. In the analysis of these indicators a special focus was put on demographic indicators. The most often used among them in the analysis so far has been the change in the number of inhabitants, the natural movement of the population, i.e. the analysis of birth and death rates, and the share of agricultural population.

Key words: social development, demographic changes, village, indicators, Romanians 